\title{
Dyscyplina w szeregach armii polsko-litewskiej na terenie Małopolski i Rusi Czerwonej w czasie przygotowań do wyprawy chocimskiej w 1621 r.
}

Wyprawa chocimska z roku 1621 należy do największych przedsięwzięć militarnych podjętych przez Rzeczpospolitą w siedemnastym stuleciu. Najazd armii osmańskiej - dowodzonej osobiście przez sułtana Osmana II - odpierało ponad trzydzieści tysięcy żołnierzy zaciężnych, nie licząc Kozaków Zaporoskich, których liczebność szacowano na 40-50 tysięcy ludzi. Toczące się we wrześniu działania wojenne opisywali Józef Tretiak ${ }^{1}$, Leszek Podhorodecki, Noj Raszba² ${ }^{2}$, Mirosław Nagielski ${ }^{3}$ oraz Petro $\mathrm{Sas}^{4}$. Działaniami chorągwi lisowskich zajmowali się Henryk Wisner ${ }^{5}$ oraz Emil Kalinowski ${ }^{6}$, zaś problemy prawne związane z próbą

* Artykuł powstał w ramach grantu Narodowego Programu Rozwoju Humanistyki nr 11H 13 033482 pt. „Akta skarbowe jako źródło do dziejów wojskowości staropolskiej za panowania Wazów (1587-1668)", realizowanego w latach 2015-2020.

1 J. Tretiak, Historia wojny chocimskiej (1621), Kraków 1921.

2 L. Podhorodecki, N. Raszba, Wojna chocimska 1621 roku, Kraków 1979; L. Podhorodecki, Kampania chocimska 1621 r., cz. 1, „Studia i Materiały do Historii Wojskowości” 1964, t. X, cz. 2, s. 88-143; cz. 2, „Studia i Materiały do Historii Wojskowości” 1965, t. XI, cz. 1, s. 37-68; idem, Chocim 1621, Warszawa 2008.

${ }^{3}$ M. Nagielski, Kozaczyzna zaporoska $w$ dobie kampanii chocimskiej 1621 roku, ,Zeszyty Naukowe Uniwersytetu Jagiellońskiego. Prace Historyczne” 2016, t. 143, z. 2, s. 277-285.

${ }^{4}$ P. Sas, Chotynśka wijna 1621 roku, Kijiw 2011; idem, Czysiel'nist' zaporoz'koho wijśka u Chotynśkij bytwy 1621 r.; idem, Szliach armiji sultana Osmana II do Chotyna $1621 \mathrm{r}$. [w:] W. Smolij, W. Stanisławśkij, T. Czuchlib, W. Kononienko, W. Matiach, B. Czerkas (red.), Ukrajina w Central'no-Schidnij Jewropi, Kijiw 2014, s. 57-70.

${ }^{5}$ H. Wisner, Lisowczycy. Łupieżcy Europy. Pierwsi polscy najemnicy, łotrzy czy bohaterowie, Warszawa 2013.

${ }^{6}$ E. Kalinowski, Z dziejów elearów polskich - Idzi Kalinowski. Część I: Od Moskwy do Chocimia, [w:] Z. Hundert, J.J. Sowa, K. Żojdź (red.), Studia nad staropolska sztuka wojenna, t. IV, Oświęcim 2015, s. 44-68. 
wykorzystania pospolitego ruszenia do działań przeciw wojskom turecko-tatarskim scharakteryzował Karol Łopatecki ${ }^{7}$. Liczebność oraz strukturę armii polsko-litewskiej badał Jan Wimmer ${ }^{8}$, zaś za sprawą Zbigniewa Hunderta oraz Karola Żojdzia światło dzienne ujrzała krytyczna edycja znajdującego się w zbiorach Biblioteki Narodowej w Warszawie komputu armii Jana Karola Chodkiewicza i Stanisława Lubomirskiego, będąca zarazem cennym zestawieniem danych zawartych w innych tego rodzaju dokumentach, powstałych w związku z wyprawą chocimską .

Celem poniższych rozważań nie jest jednak przedstawienie dziejów kampanii chocimskiej, postawiłem sobie bowiem za cel analizę stanu dyscypliny w szeregach armii polsko-litewskiej, z wyłączeniem Zaporożców, w miesiącach poprzedzających działania wojenne, a zatem mniej więcej od zakończenia obrad sejmu 1620 r., czyli od połowy grudnia 1620 r., do września roku następnego. Podstawę źródłową pracy stanowi dwanaście ksiąg relacyjnych z lat 1620-1622, pochodzących z grodów w Bełzie, Busku, Haliczu, Lwowie, Przemyślu, Sanoku, Trembowli ${ }^{10}$, Chełmie ${ }^{11}$, Bieczu, Krakowie ${ }^{12}$ oraz Lublinie $^{13}$.

W pierwszej kolejności przedmiotem moich badań stały się relacje pomiędzy żołnierzami a ludnością cywilną, przede wszystkim w kontekście szkód wojskowych, jak również przypadków, kiedy milites sami stawali się ofiarami. Punktem wyjścia były oczywiście rozważania Władysława Łozińskiego, zamieszczone na kartach Prawem i lewem, dotyczące postępowania wojska względem ludności cywilnej na Rusi Czerwonej ${ }^{14}$. Ważną rolę sui generis przewodnika pełniły również badania Tadeusza Srogosza oraz Mirosława Nagielskiego ${ }^{15}$, w mniejszym stopniu

\footnotetext{
${ }^{7}$ K. Łopatecki, Organizacja, prawo i dyscyplina w polskim i litewskim pospolitym ruszeniu (do połowy XVII wieku), Białystok 2013.

8 J. Wimmer, Wojsko i skarb Rzeczypospolitej u schyłku XVI $i$ w pierwszej połowie XVII wieku, „SMHW”, t. XIV, cz. 1, Warszawa 1968, s. 3-91.

${ }_{9}$ K. Żojdź, Z. Hundert, Komput chocimski 1621 z rękopisu Biblioteki Narodowej, [w:] Z. Hundert (red.), Studia nad staropolską sztuka wojenna, t. II, Oświęcim 2013, s. 245-257.

${ }^{10}$ Central'nyj Dierżawnyj Istorycznyj Archiw Ukrajiny m. Lwiw (dalej: CDIAUL), fond 1, opis 1 , sprawa 206 ; fond 3 , op. 1 , spr. 13 ; f. 5 , op. 1, spr. 120; f. 9, op. 1, spr. 374; f. 13, op. 1, spr. 339; f. 14, op. 1, spr. 146; f. 17, op. 1, 114.

${ }_{11}$ Nacyjanalny Histaryczny Archiw Biełarusi, Minsk (dalej: NGAB), fond 1740, op. 1, dzieło 4.

12 Archiwum Narodowe w Krakowie (dalej ANK), księgi grodzkie relacyjne: bieckie, rkps 170, krakowskie, rkps 46.

${ }^{13}$ Archiwum Państwowe w Lublinie (dalej APL), księgi grodzkie relacyjne lubelskie, RMO $50-51$.

${ }^{14}$ W. Łoziński, Prawem i lewem. Obyczaje na Czerwonej Rusi w pierwszej połowie XVII wieku, oprac. J. Tazbir, Warszawa 2005, zwłaszcza s. 161-179.

${ }_{15}$ T. Srogosz, Nastęstwa ekonomiczne wojen ze Szwecja w XVII wieku (na przykładzie województw tęczyckiego i sieradzkiego oraz ziemi wieluńskiej), [w:] B. Dybaś, A. Ziemlewska (red.),
} 
także Zbigniewa Ćwieka, Józefa Ryszarda Szaflika, Jadwigi Muszyńskiej oraz Magdaleny Wilczek-Karczewskiej ${ }^{16}$. Wypada także odnotować zbiór studiów Mirosława Nagielskiego, Krzysztofa Kossarzeckiego, Łukasza Przybyłka i Andrzeja Haratyma, poświęcony zniszczeniom w dobie potopu szwedzkiego ${ }^{17}$. Trzeba jednak pamiętać, że dotyczyły one albo szerszego lub późniejszego zakresu chronologicznego albo innego regionu Rzeczypospolitej. Księgi sądowe stwarzają także szansę przyjrzenia się sytuacji panującej w szeregach armii, zwłaszcza w kontekście dyscypliny oraz konfliktów wewnętrznych. Nieodzowną pomocą w tego rodzaju badaniach służyła rozprawa Karola Łopateckiego poświęcona prawu wojskowemu w państwie polsko-litewskim w szesnastym oraz pierwszej połowie siedemnastego wieku ${ }^{18}$.

W czasie kwerendy znalazłem w księgach grodzkich 190 wzmianek dotyczących omawianego tematu, w zdecydowanej większości protestacji, okazania ran względnie ciał domniemanych ofiar czynów zabronionych ${ }^{19}$. Poniższa tabela odzwierciedla terytorialny rozkład wzmianek poświęconych zdarzeniom z udziałem żołnierzy:

Wojny pótnocne w XVI-XVIII wieku. W czterechsetlecie bitwy pod Kircholmem, Torun 2007, s. 247-258; idem, Przemarsze i kwaterunki niekarnych oddziałów wojskowych w województwach tęczyckim i sieradzkim oraz ziemi wieluńskiej w XVII wieku, „Rocznik Łódzki”, t. XXXVII, Warszawa-Lódź 1990, s. 87-103; idem, Żotnierz swawolny. Z dziejów obyczajów armii koronnej $w$ XVII wieku, Warszawa 2010; idem, Życie codzienne żolnierzy armii koronnej i litewskiej w XVII wieku, Oświęcim 2018; M. Nagielski, Żolnierz koronny w XVII wieku, Wybawca i bohater czy ciemiężyciel $-w$ świetle zachowanych rejestrów szkód $w$ księgach grodzkich i ziemskich Rzeczypospolitej, „Społeczeństwo Staropolskie. Seria Nowa”, t. IV: Społeczeństwo a wojsko, 2015, s. $135-154$.

16 Z. Ćwiek, Z dziejów wsi koronnej XVII wieku, Warszawa 1966, zwłaszcza s. 179-181; J. Muszyńska, Straty demograficzne i zniszczenia gospodarcze w Małopolsce w połowie XVII wieku. Problemy badawcze, [w:] J. Muszyńska, J. Wijaczka (red.), Rzeczpospolita w latach Potopu, Kielce 1996, s. 275-288, J.R. Szaflik, Wieś lubelska w połowie XVII wieku. Problem zniszczeń wojennych i odbudowy, Lublin 1963; M. Wilczek-Karczewska, Szlachta wielkopolska w obliczu siedemnastowiecznych wojen. „Inter arma silent leges”, [w:] A. Jankowski, A. Klonder (red.), Cywilizacja prowincji Rzeczypospolitej szlacheckiej, Bydgoszcz 2004, s. 12-129.

${ }_{17}$ M. Nagielski, K. Kossarzecki, Ł. Przybyłek, A. Haratym, Zniszczenia szwedzkie na terenie Korony w okresie potopu 1655-1660, Warszawa 2015.

${ }^{18}$ K. Łopatecki, Disciplina militaris" w wojskach Rzeczypospolitej do połowy XVII wieku, Białystok 2012.

19 Mówiąc o wzmiankach mam na myśli dokumenty, w których wymieniono dowódców lub żołnierzy jednostek polsko-litewskich, z wyraźnym zaznaczeniem, że występują oni w tym miejscu właśnie w charakterze wojskowych. Oznacza to, że przedmiotem analizy nie były te materiały związane z osobami, znanymi skądinąd z działalności na niwie Marsa, dotyczące ich życia prywatnego czy działalności urzędowej, np. transakcji majątkowych, rozstrzygania sporów rodzinnych czy wydawania uniwersałów jako starosta czy wojewoda. 


\begin{tabular}{|c|c|}
\hline Gród & Liczba wzmianek \\
\hline Bełz & 18 \\
\hline Biecz & 12 \\
\hline Busk & 8 \\
\hline Chełm & 15 \\
\hline Halicz & 5 \\
\hline Kraków & 8 \\
\hline Lublin & 29 \\
\hline Lwów & 33 \\
\hline Przemyśl & 16 \\
\hline Sanok & 14 \\
\hline Trembowla & 32 \\
\hline Suma & 190 \\
\hline
\end{tabular}

Można przyjąć, że najważniejszą przyczyną pojawienia się licznych wzmianek wojskowych w księgach lwowskich, trembowelskich oraz lubelskich było położenie tych grodów w pobliżu tras przemarszu wojska do obozu pod Glinianami i Kamieńcem Podolskim, a w przypadku Lwowa oraz Lublina także znaczenie tych ośrodków dla wojskowej logistyki. A contrario, w odniesieniu do Biecza i Krakowa można zaryzykować twierdzenie, że te miasta znajdowały się daleko od głównych traktów komunikacyjnych i raczej nie odgrywały poważniejszej roli w zaopatrywaniu wojska w żywność i wyposażenie. Chełm oraz Bełz znajdowały się na trasie przemarszu części jednostek litewskich, które pozostawily po sobie niezbyt dobre wspomnienia. Ciekawie na tym tle przedstawia się gród w Haliczu, znajdujący się w pobliżu teatru działań wojennych, w którym odnotowano jednak niewielką liczbę zdarzeń. Skłonny byłbym wyjaśniać ten paradoks zbiorczym charakterem księgi, obejmującej dwa lata (1621-1622), powstałej prawdopodobnie z połączenia fragmentów wcześniej istniejących manuskryptów.

Skargi na zachowanie żołnierzy dotyczyły 78 jednostek, należących do niemal każdego typu formacji wojskowych występujących w komputach chocimskich, choć nie w każdym przypadku udało się jednoznacznie rozstrzygnąć, jakiego rodzaju oddziału dotyczyła skarga ${ }^{20}$. Dokładniejsze dane ilustruje poniższa tabela:

${ }^{20}$ Zwykle działo się tak w sytuacji, gdy treść skargi jednoznacznie nie rozstrzygała kwestii typu jednostki, a rotmistrz miał w kompucie dwa lub więcej oddziałów, względnie, kiedy chorągiew nie występowała w znanych zestawieniach dotyczących wyprawy chocimskiej albo w protestacji nie wpisano nazwiska dowódcy oddziału. 


\begin{tabular}{|c|c|}
\hline Typ jednostki & Liczba wzmiankowanych jednostek \\
\hline Husaria & $18^{21}$ \\
\hline Jazda kozacka & 12 \\
\hline Arkebuzeria & $0^{22}$ \\
\hline Rajtaria & 3 \\
\hline Piechota polska & 11 \\
\hline Piechota niemiecka & 8 \\
\hline Wybrańcy & 1 \\
\hline Tatarzy litewscy & 3 \\
\hline Lisowczycy & 13 \\
\hline Piechota zaciągana do Inflant & 1 \\
\hline Brak jednoznacznych danych & 10 \\
\hline Suma & 78 \\
\hline
\end{tabular}

Niektóre oddziały występują na powyższej liście więcej niż raz. Swoisty rekord ustanowił rotmistrz jednej z chorągwi lisowskich, Idzi Kalinowski, na którego skarżono się aż dziesięciokrotnie: osiem protestacji wpłynęło do grodu sanockiego, po jednej odpowiednio do halickiego oraz trembowelskiego. Niewiele mniej skarg zebrał porucznik chorągwi Tomasza Zamoyskiego, Jan Gabriel Modryński (siedem wzmianek oblatowanych w księgach bełskich), na podium uplasował się także Olbracht Odrowski vel Odorowski, rotmistrz chorągwi kozackiej (trzy wzmianki w księgach halickich oraz cztery w trembowelskich). Na czwartym miejscu znalazł się kasztelan poznański Piotr Opaliński (pięć wzmianek w księgach przemyskich), głównie za sprawą starcia z hajdukami starosty dolińskiego Jerzego Krasickiego w Przemyślu. Czterokrotnie wzmiankowano oddziały Macieja Leśniowskiego, podkomorzego bełskiego, oraz Wojciecha Zaliwskiego, Mikołaja Zborowskiego, Krzysztofa Rożniatowskiego, Gabriela Kuliczkowskiego oraz Eliasza Łowczyckiego dotyczyły po trzy, zaś dwudziestu innych dowódców po dwie wzmianki.

${ }^{21}$ Rota kasztelana poznańskiego Piotra Opalińskiego występuje w komputach jako oddział husarski, ale w protestacji mowa jest o arkebuzerach, CDIAUL, f. 13, op. 1, spr. 339, s. 1027-1029.

${ }^{22}$ Niewykluczone, że siedem skarg zaniesionych w lutym $1621 \mathrm{r}$. do grodu bełskiego przeciwko chorągwi Tomasza Zamoyskiego pod komendą porucznika Jana Gabriela Modryńskiego dotyczyło chorągwi arkebuzerskiej, zaciągniętej przez wojewodę kijowskiego na wyprawę chocimską, która jednak prawdopodobnie znalazła się w szeregach wojsk towarzyszących Zygmuntowi III, CDIAUL, f. 1, op. 1, spr. 206, s. 83-87; Archiwum Główne Akt Dawnych w Warszawie, Archiwum Skarbu Koronnego, dz. II, rkps 42, k. 207. Nie bardzo wiadomo także, jakiego rodzaju oddziałem dowodził inny rotmistrz Tomasza Zamoyskiego, Jan Świeżyński, CDIAUL, f. 3, op. 1, spr. 13, s. 185-186. 
W księgach grodzkich odnotowano szkody poczynione w ośmiu większych ośrodkach miejskich (Biecz, Bochnia, Lublin, Lwów, Olkusz, Przemyśl, Tarnopol, Sądowa Wisznia) oraz 76 miasteczkach, wioskach i kluczach dóbr. Wśród poszkodowanych znaleźli się mieszkańcy dziesięciu starostw (bełskiego, buskiego grodeckiego, jaworowskiego, kamionackiego, krasnostawskiego, lwowskiego, parczewskiego, ratneńskiego sokalskiego, oraz tarnogórskiego). Skargi na wojsko składały także instytucje kościelne: kapituły krakowska, chełmska oraz przemyska, konwenty dominikanów lwowskich, karmelitów trembowelskich oraz jezuitów lubelskich, nie zapominając o plebanie tarnopolskim Szymonie Lorensowiczu. Wśród ofiar przestępstw znaleźli się także żołnierze, w księgach odnotowano siedemnaście przypadków, kiedy sprawcą byli milites z innych rot, siedem, kiedy szkoda powstała wskutek działania towarzyszy broni względnie członków własnego pocztu. Wypadałoby także wspomnieć o pięciu skargach związanych z dezercją z szeregów. Do osobnej kategorii zdarzeń należy zaliczyć przypadki, w których wojsko oskarżało o wyrządzenie szkód ludność cywilną. W księgach odnotowano osiemnaście tego rodzaju zdarzeń.

Prawo oraz dyscyplinę w wojsku regulowały przede wszystkim uchwalone przez sejm Artykuty wojenne hetmańskie, authoritate sejmu aprobowane anni $1609^{23}$ wraz z licznymi ustawami sejmowymi z czasów Zygmunta III Wazy, w tym podsumowującą dotychczasowy dorobek ustawodawczy szlacheckiego parlamentu konstytucją Porządek około zachowania żotnierza z 1609 r., dotyczące głównie stacjonujących na pograniczu rot kwarcianych ${ }^{24}$. Normy prawne zakazywały żołnierzom zatrzymywania się na leżach czy przystawstwach w dobrach szlacheckich, zezwalając na pobyt w królewszczyznach, jak również, od 1609 r., w posiadłościach należących do duchownych. Złamanie zakazu było opatrzone sankcją w wysokości 100 grzywien ${ }^{25}$ oraz obowiązkiem naprawienia wyrządzonych szkód. Maszerujące oddziały królewskie spędzić mogły we wsi lub mieście wyłącznie jedną noc. Podczas pobytu wojsko powinno było kupować żywność w cenach określonych w hetmańskim cenniku, przewidziano wszak od tej reguły istotny wyjątek: w przypadku sprzedaży wołów, jałowic, ryb, przypraw oraz napojów (,picia”) cenę zakupu ustalały dobrowolnie strony. Normy prawne nie

${ }^{23}$ Volumina Constitutionum, t. II, vol. 2, red. S. Grodziski, Warszawa 2008, s. 402-408, zob. K. Łopatecki, ,Disciplina militaris”..., s. 602-644.

${ }^{24}$ VC, t. II, vol. 2, s. 80, O żolnierzach (sejm koronacyjny 1588 r.); s. 176-178, Disciplina militaris (sejm 1590/1591); s. 199, Obrona z kwarty (sejm 1593 r.); s. 381, Porzadek około zachowania żotnierza (sejm 1609 r.); s. 383, O zabronieniu powod i niestawieniu na stużbę, tak w Koronie jako $i$ wielkim Księstwie Litewskim (sejm 1609 r.); VC, t. III, vol. 1, red. S. Grodziski, M. Kwiecień, A. Karabowicz, Warszawa 2010, s. 119, sejm zwyczajny 1613 r., O kwarcianym żotnierzu; s. 271, Dyscyplina militaris (sejm zwyczajny 1620 r.), K. Łopatecki, „, Disciplina militaris”, s. 653-676.

${ }^{25}$ Licząc grzywnę jako ekwiwalent 48 groszy uzyskać można kwotę 4800 groszy, czyli 160 zł, zob. J. Szymański, Nauki pomocnicze historii, Warszawa 2001, s. 578-589. 
dopuszczały możliwości zabierania żywności siłą, ale w tym przypadku istnieje rozbieżność co do kary: konstytucja sejmu 1590/1591 przewidywała odpowiedzialność w postaci kary 14 grzywien (ok. 22 zł) wraz z obowiązkiem odszkodowawczym, podczas gdy „Artykuły wojenne” pozostawiały sankcję do uznania hetmanowi.

Równocześnie „Artykuły wojenne” zakazywały zabierania innych rzeczy niż żywność oraz rozbijania komór, traktując takie czyny jako równoznaczne z kradzieżą, podobnie jak niszczenie pasiek (art. 13 oraz 17). Zabranie wołu w świetle tego aktu prawnego narażało sprawcę na obowiązek zapłaty jego równowartości, wedle wyceny poszkodowanego (art. 22). Żołnierze nie mogli także odławiać ryb ze stawów hodowlanych oraz rozkopywać oraz spuszczać z nich wody, za co groziła śmierć przez powieszenie (art. 14). Ustawodawca wspomniał również w osobnym artykule o zakazie wyrządzania szkód w młynach oraz karczmach, nakazując sprawcy zapłatę kwoty stanowiącej czterokrotność wyrządzonej szkody. Tak „Artykuły wojenne”, jak konstytucje sejmowe konsekwentnie zakazywały zabierania chłopom i mieszczanom koni oraz wozów jako środków transportu, czyli tzw. podwód. „Artykuły wojenne” traktowały ten czyn na równi z kradzieżą, chyba że żołnierz chciał w ten sposób zastąpić konia, który zdechł lub do jego utraty doszło z powodu ucieczki woźnicy, ale nawet wówczas istniała konieczność uzyskania dobrowolnej zgody właściciela wsi lub starszego (art. 24). Konstytucja sejmu 1590/1591 r. przewidywała natomiast za zabór koni i wozów analogiczną karę, jak za przymusowe zabieranie żywności.

Przewidując nadchodzącą wojnę, sejm 1620 r. uchwalił konstytucję „Ciągnienie żołnierza”, która dokonywała reasumpcji wcześniejszych ustaw regulujących materię stacji, disciplinae militaris oraz przemarszów wojskowych. W tej ostatniej kwestii konstytucja wprowadzała także istotną zmianę, zezwalając na nocleg i branie pokarmów w dobrach królewskich i duchownych tylko dwóm rotom, których dowódcy, rotmistrzowie lub porucznicy zostali zobowiązani do wystawienia atestacji potwierdzającej fakt pobytu w dobrach. Odmowa wystawienia takiego dokumentu oznaczać miała pozbawienie stopnia i wytrąbienie z wojska na mocy wyroku hetmana i komisarzy. Analogiczna kara dotyczyć powinna tych oficerów, którzy wprowadzą swoją jednostkę jako trzecią do dóbr, w których stacjonowały już dwie chorągwie ${ }^{26}$.

Analiza zawartych w księgach grodzkich protestacji wskazuje, że opisane powyżej w skrótowej formie nakazy i zakazy pozostawały w wielu przypadkach martwą literą. Przede wszystkim żołnierze zabierali żywność bez zapłaty. Łupem milites padało różnego rodzaju zboże: pszenica, żyto, jęczmień, owies czy

${ }^{26}$ VC, t. III, vol. 1, s. 267-268. 
gryka, a także groch, rośliny ogrodowe oraz siano ${ }^{27}$. W niektórych przypadkach sprawcy nie ograniczyli się wyłącznie do zabrania zboża, ale poczynili również zniszczenia w zasiewach ${ }^{28}$. W większości przypadków łupem żołnierzy padały także mąka, chleb, kasze, krupy, masło, jaja, sery, mięso czy słonina ${ }^{29}$. Spragnieni wojacy nie mogli się powstrzymać przed zabieraniem piwa oraz gorzałki ${ }^{30}$. Źródła wspominają też - choć rzadziej i wyłącznie w odniesieniu do ośrodków miejskich - o zabieraniu przypraw, np. pieprzu czy imbiru ${ }^{31}$. Łupem żołnierzy padał inwentarz żywy: kury, kaczki, gęsi, krowy, owce, barany czy świnie ${ }^{32}$ oraz,

${ }^{27}$ Dla przykładu CDIAUL, f. 17, op. 1, spr. 114, s. 699-700, skarga Elżbiety Chodorowskiej przeciwko rotmistrzowi Gabrielowi Kuliczkowskiemu i jego rocie o wyciąganie stacji w Koszowej; ibid., f. 1, op. 1, spr. 206, skarga chłopów ze wsi Butyny przeciwko porucznikowi chorągwi wojewody kijowskiego T. Zamoyskiego, Janowi Gabrielowi Modryńskiemu oraz jego podkomendnym; ibid., f. 3, op. 3, spr. 13, relacja o położeniu pozwu na Trybunał Lubelski przez Reginę Żółkiewską, wdowę po hetmanie wielkim koronnym Stanisławie Żółkiewskim przeciwko chorągwi Tomasza Zamoyskiego dowodzonej przez Jana Świeżyńskiego o szkody poczynione w Kamionce ibid., f. 15, op. 1, spr. 146, s. 823-829, skarga Jerzego Krasickiego, chorążego halickiego i starosty dolińskiego przeciwko rotmistrzowi Władysławowi Stadnickiemu; ibid., f. 9, op. 1, spr. 374, s. 856-857, skarga Jadwigi Dzierznickiej przeciwko oberszterowi Hansowi Georgowi von Arnim; APL, RMO 51, k. 175v.-177, skarga lubelskiego kolegium jezuitów przeciwko rotmistrzowi jazdy Marcinowi Kochanowskiemu.

${ }^{28}$ APL, RMO 51, k. 660-661v., relacja woźnego w sprawie zniszczeń w starostwach krasnystawskim i tarnogórskim.

${ }^{29}$ Dla przykładu: CDIAUL, f. 1, op. 1, spr. 206, s. 222-225, skarga mieszkańców wsi Sielce, Parchać, Cebłów oraz Góra przeciwko chorągwi Macieja Leśniowskiego, podkomorzego bełskiego; APL, RMO 51, k. 284-286, skarga poddanych Pawła Orzechowskiego z Bełżyc przeciwko Michałowi Mszalskiemu, porucznikowi chorągwi lisowskiej Marcina Jaskulskiego; NGAB, f. 1740, op.1, dz. 4, k. 594-595v., skarga Pawła Orzechowskiego złożona za pośrednictwem sługi Klemensa Górskiego przeciwko porucznikowi roty Fedora Hłuszanina, Szymonowi Jankowskiemu o szkody poczynione w Skurdejowie.

${ }^{30}$ CDIAUL, f. 1, op. 1, spr. 206, s. 287-289, skarga Jana Kuczyńskiego (?), złożona w imieniu Janusza Prusinowskiego, przeciwko rotmistrzowi Wojciechowi Mniszkowi o szkody w Przyspie oraz Żukowie; ibidem, f. 3, op. 3, spr. 13, relacja o położeniu pozwu na Trybunał Lubelski przez Reginę Żółkiewską, wdowę po hetmanie wielkim koronnym Stanisławie Żółkiewskim przeciwko chorągwi Tomasza Zamoyskiego dowodzonej przez Jana Świeżyńskiego o szkody poczynione w Kamionce; ibid., f. 17, op. 1, spr. 114, s. 984-989, skargi Anny Cetnerówny Baworowskiej przeciwko rotmistrzom lisowskim: Staroniowi (?) i Adamowi Skowieskiemu, o szkody poczynione w Baworowie oraz Grabowcu.

${ }^{31}$ CDIAUL, f. 15, op. 1, spr. 146, s. 839-842, oblata 14 sierpnia 1621, skarga wojewody derpskiego Mikołaja Kiszki przeciwko rotmistrzowi lisowczyków Pawłowi Monisławskiemu i jego towarzystwu o szkody poczynione w Lesku; APL, RMO 51, k. 390v., skarga mieszkańców Kurowa przeciwko Mikołajowi Mszalskiemu, porucznikowi roty Jaskólskiego.

32 CDIAUL, f. 15 , op. 1, spr. 146, s. 823-829, skarga Jerzego Krasickiego, chorążego halickiego i starosty dolińskiego przeciwko Władysławowi Stadnickiemu; ibid., f. 1, op. 1, spr. 206, s. 299-301, skarga Wojciecha Woyny w imieniu Anny Rudgierdówny przeciwko Janowi Bokiejowi, rotmistrzowi województwa wołyńskiego oraz porucznikowi jego roty Bojanowskiemu o szkody poczynione w Łuczycach, Bujawie i Szarpamie (Szarpawie?); ibidem, s. 577-578, skarga Andrze- 
pomimo zakazów, także woły oraz konie ${ }^{33}$. W przypadku, kiedy pokrzywdzeni nie posiadali żywności określonego rodzaju lub mieli jej zbyt mało, musieli płacić żołnierzom pieniądze na jej zakup ${ }^{34}$.

Nie do pogardzenia dla militum były narzędzia rolnicze i rzemieślnicze oraz różne przedmioty z żelaza: siekiery, sierpy, rydle, świdry, motyki, narzędzia kowalskie itp. ${ }^{35}$ Żołnierze poprzez grabież zaopatrywali się w garderobę - o dziwo również damską - oraz buty ${ }^{36}$. Ze szlacheckich, chłopskich oraz mieszczańskich domów zabierano broń, głównie szable i rusznice ${ }^{37}$. Nie oszczędzano także stawów, spuszczając $\mathrm{z}$ nich wodę poprzez przekopanie grobli i wyłapując $\mathrm{w}$ ten

ja Majera, sługi Jana Farensbacha, starosty lemzelskiego, na Wilhelma Grana, Jachyma, Wienca (Ywienca?), kapitanów w regimencie Gerarda Denhoffa o szkody poczynione w dobrach Kryłów; NGAB, f. 1740, op. 1, dz. 4, k. 639v., skarga Pawła Orzechowskiego (w jego imieniu wystąpił Stanisław Górski) przeciwko rotmistrzowi Aleksandrowi Ogińskiemu, o szkody poczynione w Drohusku, Turku i Skurdejowie.

${ }^{33}$ CDIAUL, f. 5, op. 1, spr. 120, s. 254-255; skarga Stefana Gdeszyńskiego przeciwko Liwińskiemu oraz Idziemu Kalinowskiemu o szkody poczynione w dobrach Fordonice oraz Krzywotuły; ibid, f. 9, op. 1, spr. 374, s. 574, skarga Jana Chełmowskiego, famuli starosty hrubieszowskiego Jana Żółkiewskiego przeciwko Joannesowi Foytowi, Szkotowi, rotmistrzowi w pułku Piotra Learmonta o szkody poczunione we wsi Kumin w starostwie jaworowskim; NGAB, fond 1740, opis 1, dzieło 4, k. 578v.-580v., skarga Władysława Ostroroga przeciwko porucznikowi roty Fedora Hłuszanina, Szymonowi Jarkowskiemu vel Jankowskiemu o szkody poczynione w tenucie Stolno.

${ }^{34}$ Dla przykładu CDIAUL, f. 17, op. 1, spr. 114, s. 697-699, skarga Elżbiety Chodorowskiej przeciwko rotmistrzowi Olbrachtowi Odorowskiemu i jego rocie o wyciąganie stacji w Koszowej; ibid., f. 15, op. 1, spr. 146, s. 823-829, skarga Jerzego Krasickiego, chorążego halickiego i starosty dolińskiego przeciwko rotmistrzowi Władysławowi Stadnickiemu.

${ }^{35}$ CDIAUL, f. 1, op. 1, spr. 206, s. 287-289, skarga Jana Kuczyńskiego (?), złożona w imieniu Janusza Prusinowskiego przeciwko rotmistrzowi Wojciechowi Mniszkowi o szkody w Przyspie oraz Żukowie, ibidem, f. 15, op. 1, spr. 146, s. 839-842, oblata 14 sierpnia 1621, skarga wojewody derpskiego Mikołaja Kiszki przeciwko rotmistrzowi lisowczyków Pawłowi Monisławskiemu i jego towarzystwu o szkody poczynione w Lesku; NGAB, f. 1740, op. 1, dz. 4, k. 639v., skarga Pawła Orzechowskiego (w jego imieniu wystąpił Stanisław Górski) przeciwko rotmistrzowi Aleksandrowi Ogińskiemu, o szkody poczynione w Drohusku, Turku i Skurdejowie.

${ }^{36}$ CDIAUL, f. 9, op. 1, 374, s. 723, skarga uczciwej Agnieszki, żony Wasyla Kozaka przeciwko towarzyszowi roty kozackiej Krzysztofa Rożniatowskiego; CDIAUL, f. 1, op. 1, spr. 206, s. 577578, skarga Andrzeja Majera, sługi Jana Farensbacha, starosty lemzelskiego, przeciwko Wilhelmowi Granowi, Jachymowi, Wiency (Ywiency?), kapitanów w regimencie Gerarda Denhoffa o szkody poczynione w dobrach Kryłów; ibid., f. 15, op. 1, spr. 146, s. 823-829, skarga Jerzego Krasickiego, chorążego halickiego i starosty dolińskiego przeciwko rotmistrzowi Władysławowi Stadnickiemu.

37 CDIAUL, f. 5, op. 1, spr. 120, s. 254-255; skarga Stefana Gdeszyńskiego przeciwko Liwińskiemu oraz Idziemu Kalinowskiemu o szkody poczynione w dobrach Fordonice oraz Krzywotuły; ibid., f. 15, op. 1, spr. 146, s. 839-842, oblata 14 sierpnia 1621, skarga wojewody derpskiego Mikołaja Kiszki przeciwko rotmistrzowi lisowczyków Pawłowi Monisławskiemu i jego towarzystwu o szkody poczynione w Lesku; ibid., f. 17, op. 1, spr. 114, s. 869-870 oblata 25 czerwca 1621, skarga poddanych Piotra Ożgi przeciwko rotmistrzowi kozackiemu Zaleskiemu i jego podkomendnym o najście na dom w Siemianowej. 
sposób ryby ${ }^{38}$. W źródłach znalazły się również wiadomości o szkodach poczynionych w karczmach oraz młynach ${ }^{39}$. Często pojawiają się wzmianki o zabieraniu koni oraz wozów jako podwód, prawdopodobnie w celu przetransportowania zrabowanych przedmiotów ${ }^{40}$. Zdarzały się także przypadki niszczenia sprzętów domowych, a nawet uszkadzania budynków, zwykle poprzez niszczenie okien i drzwi ${ }^{41}$. Warto jednak odnotować, że w aktach grodzkich odnaleziono jedynie jedną wiadomość o próbie podpalenia zabudowańn ${ }^{42}$.

Osobną grupe protestacji stanowią skargi dotyczące naruszenia konstytucji sejmu 1620 r. „Ciągnienie żołnierza”, choć należy podkreślić, że zwykle znajdowały się w niej - obok zarzutu naruszenia postanowień tego prawa polegającego na zajęciu stanowiska $\mathrm{w}$ dobrach skarżącego, pomimo przedstawienia atestacji potwierdzających fakt uprzedniego zajmowania stanowisk przez dwie chorągwie,

${ }^{38}$ CDIAUL, f. 17, op. 1, spr. 114, s. 874-876, oblata 28 czerwca 1621, skarga Anny z Charbinowic Chodorowskiej przeciwko Aleksandrowi Kowynickiemu, porucznikowi chorągwi Srzedzińskiego z pułku Tomasza Zamoyskiego w dobrach Złotniki; ibidem, f. 17, op. 1, spr. 114, s. 984-989, skargi Anny Cetnerówny Baworowskiej przeciwko rotmistrzom lisowskim: Staroniowi (?) i Adamowi Skowieskiemu, o szkody poczynione w Baworowie oraz Grabowcu.

${ }^{39}$ CDIAUL, f. 13, op. 1, spr. 339, s. 1638-1639 (1647-1648), skarga Jana Korytki przeciwko rotmistrzowi Broskowskiemu o zajęcie na czele 60 piechurów wioski Zarzecze i szkody poczynione w tamtejszej karczmie; ANK, księgi grodzkie bieckie, rkps 170, s. 1220-1225, reprotestacja mieszczan bieckich wraz z protestacją młynarza Tomasza Serafina oraz wizją lokalną przeprowadzoną przez woźnego przeciwko chorągwi Kaspra Sobiekurskiego.

${ }^{40}$ CDIAUL, f. 9, op. 1, spr. 374, s. 576, oblata 19 lipca 1621, skarga uczciwego Andreasa Oleksaka ze wsi Brzuchowice przeciwko Kopeckiemu, towarzyszowi roty Mikołaja Zborowskiego z Rytwian o zabór dwóch koni wraz z wozem pod pozorem podwody; ibid., f. 17, op. 1, spr. 114, s. 699-700, skarga Elżbiety Chodorowskiej przeciwko rotmistrzowi Gabrielowi Kuliczkowskiemu i jego rocie o wyciąganie stacji w Koszowej; NGAB, fond 1740, opis 1, dzieło 4, k. 578v.-580v., skarga Władysława Ostroroga przeciwko porucznikowi roty Fedora Hłuszanina, Szymonowi Jarkowskiemu vel Jankowskiemu o szkody poczynione w tenucie Stolno; APL, RMO 51, k. 236v.-237, Wielka Sobota (10 kwietnia 1621) 1621, skarga magistratu lubelskiego przeciwko rotmistrzowi piechoty wybranieckiej z województw bełskiego i lubelskiego, Stanisławowi Słupskiemu.

${ }^{41}$ CDIAUL, ibid., f. 3, op. 3, spr. 13, relacja o położeniu pozwu na Trybunał Lubelski przez Reginę Żółkiewską, wdowę po hetmanie wielkim koronnym Stanisławie Żółkiewskim przeciwko chorągwi Tomasza Zamoyskiego dowodzonej przez Jana Świeżyńskiego o szkody poczynione w Kamionce, ibid., f. 15, op. 1, spr. 146, s. 839-842, oblata 14 sierpnia 1621, skarga wojewody derpskiego Mikołaja Kiszki przeciwko rotmistrzowi lisowczyków Pawłowi Monisławskiemu i jego towarzystwu o szkody poczynione w Lesku; ibidem, f. 17, op. 1, spr. 114, s. 984-989, skargi Anny Cetnerówny Baworowskiej przeciwko rotmistrzom lisowskim: Staroniowi (?) i Adamowi Skowieskiemu, o szkody poczynione w Baworowie oraz Grabowcu; APL, RMO 50, s. 701-702, 4 grudnia 1620, relacja woźnego na temat szkód, poczynionych w Siehaczowie (Sahaczowie) przez rotmistrzów Bronickiego oraz Szostaka z pułku Rogawskiego oraz Przetockiego z pułku Falęckiego.

${ }^{42}$ CDIAUL, ibid., f. 3, op. 3, spr. 13, relacja o położeniu pozwu na Trybunał Lubelski przez Reginę Żółkiewską, wdowę po hetmanie wielkim koronnym Stanisławie Żółkiewskim przeciwko chorągwi Tomasza Zamoyskiego dowodzonej przez Jana Świeżyńskiego o szkody poczynione w Kamionce. 
wystawionych przez ich dowódców - bardziej „standardowe” oskarżenia o wyciąganie stacji, kradzieże, zniszczenie mienia oraz pobicia mieszkańców ${ }^{43}$.

Ofiarami przemocy ze strony żołnierzy padali mieszkańcy wsi i miasteczek, mając wątpliwe szczęście gościć u siebie wojsko. Najczęściej przybierała ona postać różnego rodzaju pobić ${ }^{44}$, ale w źródłach odnotowano także przypadki torturowania chłopów, prawdopodobnie w celu uzyskania wiadomości o miejscu ukrycia cennych przedmiotów ${ }^{45}$. O szczęściu mówić mogą rzemieślnicy, którzy - co prawda - nie uzyskali zapłaty za swą pracę, ale też nie doznali żadnych szkód cielesnych $^{46}$. Sporadycznie można się natknąć na przypadki oskarżeń o uprowadzenie i przetrzymywanie albo o zabójstwo ${ }^{47}$. Osobną grupę oskarżeń stanowią

${ }^{43}$ CDIAUL, f. 1, op. 1, spr. 206, s. 264, protestacja Jakuba Kazimierza Piaseckiego, sługi kasztelana krakowskiego Jerzego Zbaraskiego przeciwko towarzyszom z roty Macieja Leśniowskiego, podkomorzego bełskiego o szkody poczynione w starostwie sokalskim, gdzie rota zatrzymała się jako czwarta z kolei; APL, księgi grodzkie lubelskie, RMO 51, k. 270-271, skarga wójta Biskupic przeciwko żołnierzom Wawrzyńca (s) Słupskiego, którzy wkroczyli do miasta pomimo przedstawienia atestacji, potwierdzających stacjonowanie w dobrach rot Stanisława Jaroszowskiego oraz Jana Rozdrażewskiego; ibidem, k. 283-283v., skarga Jana Tudorowskiego przeciwko rotmistrzowi tatarskiemu Carewiczowi, który wbrew prawu wkroczył do starostwa parczowskiego, nie bacząc na atestacje rotmistrzów: Jaroszowskiego, dowodzącego kozakami, Platemberga (rajtarzy) oraz Ryszkowskiego.

${ }^{44}$ CDIAUL, f. 1, op. 1, spr. 206, s. 577-578, skarga Andrzeja Majera, sługi Jana Farensbacha, starosty lemzelskiego, przeciwko Wilhelmowi Granowi, Jachymowi, Wiencowi (Ywiencowi?), kapitanom w regimencie Gerarda Denhoffa o szkody poczynione w dobrach Kryłów ibid., f. 17, op. 1, spr. 114, s. 857-858, skarga Marcina Wolanowskiego przeciwko Sazaszwemu (?), rotmistrza JKM o napaść na dwór i dobra protestującego; APL, RMO 51, k. 261 v., skarga Wojciecha Wereszczyńskiego z powiatu chełmskiego przeciwko rotmistrzowi Fedorowi Hłuszaninowi z pułku Chodkiewicza oraz jego porucznikowi Jankowskiemu o szkody poczynione w Końskiej Woli; NGAB, fond 1740, opis 1, dz. 4, k. 479, protestacja Jana Śliwiwskiego przeciwko Janowi Konickiemu towarzyszowi (commilitoni) roty Jerzego Łady.

${ }^{45}$ CDIAUL, f. 15 , op. 1, spr. 146, s. 829-833, protestacja starosty dolińskiego Jerzego Krasickiego przeciwko Władysławowi Stadnickiemu i Pobidzińskiemu, jednemu z chłopów z Śliwnicy wkręcano palec w kurek pistoletu, aby wskazał miejsce ukrycia żywności; NGAB, fond 1740, opis 1, dzieło 4, k. 594-595v., skarga Pawła Orzechowskiego, złożona za pośrednictwem sługi Klemensa Górskiego przeciwko porucznikowi roty Fedora Hłuszanina, Szymonowi Jankowskiemu, o szkody w Skurdejowie.

${ }^{46}$ CDIAUL, ibidem, f. 3, op. 3, spr. 13, relacja o położeniu pozwu na Trybunał Lubelski przez Reginę Żółkiewską, wdowę po hetmanie wielkim koronnym Stanisławie Żółkiewskim przeciwko chorągwi Tomasza Zamoyskiego dowodzonej przez Jana Świeżyńskiego o szkody poczynione w Kamionce; NGAB, fond 1740, opis 1, dzieło 4, k. 594-595v., skarga Pawła Orzechowskiego, złożona za pośrednictwem sługi Klemensa Górskiego przeciwko porucznikowi roty Fedora Hłuszanina, Szymonowi Jankowskiemu, o szkody w Skurdejowie; APL, RMO 51, k. 235-236, oblata wielka sobota (10 kwietnia 1621), skarga magistratu lubelskiego przeciwko rotmistrzowi piechoty Markowi Malickiemu.

${ }^{47}$ Uprowadzenie: CDIAUL, f. 3, op. 1, spr. 13, s. 174-176, skarga poddanych z wsi należących do starostwa buskiego przeciwko rotmistrzowi Maciejowi Leśniowskiemu, podkomorzemu bełskiemu; NGAB, f. 1740, op. 1, dz. 4, k. 639v., skarga Pawła Orzechowskiego (w jego imieniu wystąpił 
zarzuty usilstwa (zgwałcenia). W księgach znalazły się jedynie cztery protestacje dotyczące tego przestępstwa, z czego nie należy jednak wyciągać wniosku, że były to jedyne przypadki stuprum ${ }^{48}$.

Bodaj najgłośniejszym echem spośród powyższych spraw odbił się krwawy spór pomiędzy towarzystwem chorągwi husarskiej albo arkebuzerskiej - o obu typach jednostki mowa jest w źródłach - kasztelana poznańskiego Piotra z Bnina Opalińskiego z hajdukami starosty dolińskiego i chorążego halickiego Jerzego Krasickiego, do którego doszło w przemyskiej katedrze 19 maja 1621 r. Kiedy celebrowano akt pojednania pomiędzy podczaszym przemyskim Piotrem Bolestraszyckim a jednym z towarzyszy spod komendy pana poznańskiego, do kaplicy Drohojowskich wdarł się Krasicki wraz z synem Stanisława „Diabła” Stadnickiego Zygmuntem i liczną grupą zbrojnych, po czym zelżył towarzystwo Opalińskiego. W rezultacie doszło do pojedynku pomiędzy panem chorążym a niejakim Mielżyńskim, prawdopodobnie Krzysztofem, oraz strzelaniny, zapoczątkowanej przez hajduków, o której skali świadczy fakt, że wedle biskupa przemyskiego Jana Wężyka w kaplicy znaleziono siedem kul. Biskup rzucił na Przemyśl interdykt, zaś podkomendni Opalińskiego oblegli dwór Krasickiego w Przemyślu zwany Żupą, który zdobyli szturmem dopiero po trzech dniach, przy okazji zabijając Tomasza Gierałtowskiego oraz Szczęsnego Tyrawskiego, jednego ze sług starosty dolińskiego. Pokonany Krasicki musiał wystawić podkomendnym Opalińskiego pisemne zobowiązanie, że bierze na siebie ciężar przekonania biskupa do otwarcia kościołów w Przemyślu, z czego chorąży halicki wycofał się zaraz po opuszczeniu miasta przez chorągiew pana poznańskiego. Towarzystwo kasztelańskiej chorągwi postarało się także o „świadectwo moralności”, wystawione przez grupę urzędników ziemskich oraz szlachty przemyskiej (Mikołaj Kozłowski, sędzia ziemski przemyski, Piotr Bolestraszycki, podczaszy przemyski, Paweł

Stanisław Górski) przeciwko rotmistrzowi Aleksandrowi Ogińskiemu, o szkody poczynione w Drohusku, Turku i Skurdejowie; zabójstwo: ANK, księgi grodzkie bieckie, rkps 170, s. 1268-1269, okazanie zwłok Agnieszki, służącej Barbary Głazowskiej, śmiertelnie postrzelonej przez Gościeńskiego, sługę rotmistrza Kaspra Sobiekurskiego.

${ }^{48}$ CDIAUL, f. 15 , op. 1, sp. 146, s. 966-967, skarga mieszkańców wsi Wróblik przeciwko Kamińskiemu, słudze rotmistrza Idziego Kalinowskiego o zgwałcenie dziewczyny imieniem Agnieszka; ibid., f. 17, op. 1, spr. 114, s. 716-717, skarga mieszkanki Czelejowa, pracowitej Kachny (?), przeciwko Kuliczkowskiemu, towarzyszowi z chorągwi Gabriela Kuliczkowskiego oraz jego pomocnikom o zgwałcenie; NGAB, fond 1740, opis 1, dzieło 4, k. 595v., skarga sławetnych Doroty Steczkowej oraz jej córki Anny Wirchowej przeciwko Mikołajowi Rybickiemu, towarzyszowi z roty Fedora Hłuszanina; ANK, księgi grodzkie krakowskie, rkps 46, s. 1687-1688, skarga Reginy, córki Jerzego Bączalskiego na lisowczyków: Stanisława Białobrzeskiego jako prycypała oraz Wyrzykowskiego o zbrojne najście na dom w Krakowie oraz zgwałcenie, więcej na temat tego przestępstwa T. Srogosz, Żolnierz swawolny..., s. 194-195, który odnotował 13 przypadków zgwałcenia na 609 protestacji. 
Zieleński, Samuel, Jan, Stefan oraz Gerasim Bolestraszyccy, Piotr Romer), które następnie oblatowali w aktach grodzkich ${ }^{49}$.

Grodzkie księgi sądowe pozwalają jednak śledzić nie tylko przestępstwa popełniane przez żołnierzy względem ludności cywilnej, ale także sytuacje, kiedy sprawca i ofiara zamieniają się miejscami, a żołnierz doznaje szkód z rąk ludności cywilnej. W kilku przypadkach skardze złożonej przez żołnierzy towarzyszy reprotestacja wniesiona przez domniemanych sprawców, co nakazuje poddać w wątpliwość niewinność oskarżyciela. Dla przykładu 30 kwietnia w grodzie bieckim oblatowane zostały: relacja o położeniu pozwu oraz protestacja rotmistrza Kaspra Sobiekurskiego oraz porucznika jego roty, Marcjana Pągowskiego przeciwko mieszczanom bieckim. Obaj zarzucali adwersarzom, że nie wpuścili chorągwi na postój oraz dokonali napaści - z użyciem broni palnej - na chorągiew opuszczającą przedmieścia, raniąc przy tej okazji kilku towarzyszy. Na odpowiedź oskarżonych nie trzeba było długo czekać, tydzień później także władze miejskie dokonały wpisu reprotestacji, do której dołączono skargę miejscowego młynarza, Tomasza Serafina oraz przeprowadzoną przez woźnego wizję lokalną. Mieszczanie thumaczyli odmowę wpuszczenia wojska do miasta tym, że nie okazano ani im, ani miejscowemu podstarościemu listu przypowiedniego. Twierdzili także, że w czasie trzech dni pobytu (od piątku do niedzieli, 30 kwietnia - 2 maja) na przedmieściach żołnierze wyrządzili mieszkańcom liczne szkody. Szczególnie poszkodowany miał być Serafin, któremu zabrano słód, pszenicę, żyto, mąkę żytnią, różne narzędzia oraz damskie i męskie ubrania. Zniszczono zamki do skrzyń oraz drzwi, a także pomieszczenia młyńskie ${ }^{50}$.

49 Sztokholm, Riksarkivet, Extranea IX Polen, sygn. 99, niepaginowana, J. Wężyk do W. Gembickiego, Buszów 23 V 1621; CDIAUL, f. 14, op. 1, spr. 339, s. 1017-1023, 1054-1056; 1071-1076, 1330-1331; o sprawie pisał - wyłącznie w oparciu ww. księgę - W. Łoziński, Prawem i Lewem..., s. $484-485$.

${ }^{50}$ ANK, księgi grodzkie bieckie, rkps 170, s. 1212-1216, 1220-1225; zob. także ibidem, s. 1243-1247, protestacje towarzystwa chorągwi Idziego Kalinowskiego oraz samego rotmistrza przeciwko władzom miasta Bochni, o tej sprawie pisał E. Kalinowski, op.cit., s. 66-67, gdzie mowa także o skardze Mikołaja Moczarskiego przeciwko Olkuszowi; CDIAUL, f. 9, op. 1, spr. 374, s. 657-659, 694-695, skarga rotmistrza Henryka Szmelinga przeciwko szlachcicowi z powiatu bełskiego Janowi Jarczewskiemu oraz proclamatio capitis sługi Jarczewskiego, Marcina Węgra, domniemanej ofiary Szmelinga; ibid., f. 17, op. 1, spr. 114, s. 930-931, 934-936 skarga towarzyszy z chorągwi Janusza Kiszki, starosty parnawskiego o napaść w czasie postoju w Tarnopolu; oraz skarga mieszczan tarnopolskich na rotę Janusza Kiszki i wymienionych w powyższej protestacji towarzyszy o napaść zbrojną, zadanie ran oraz zabór koni do podwód; ibidem, s. 597-600, skarga karmelitów z konwentu trembowelskiego, okazanie ran zadanych w domu niejakiego Wierzbięty w Trembowli przez Józefa Popiołka i jego wspólników mnichowi Sewerynowi; protestacja Jana Wierzejskiego, towarzysza chorągwi Józefa Anibala przeciwko przeorowi oraz braciom konwentu karmelitów w Trembowli. protestacja Grzegorza Popiołka towarzysza roty Józefa Anibala przeciwko tymże o zranienie na kwaterze w Trembowli. 
W księdze halickiej odnotowano w pierwszej połowie sierpnia 1621 r. gwałtowny spór pomiędzy Krzysztofem Kaweckim, towarzyszem chorągwi kozackiej Olbrychta Odrowskiego (Odorowskiego) a Janem Piekarskim, dzierżawcą wsi Łysiec, której właścicielem był przebywający w niewoli książę Samuel Korecki. Pierwszy z wymienionych zarzucał Piekarskiemu oraz mieszkańcom wsi zawłaszczenie należących doń rzeczy, głównie koni, siodeł, ubrań, rynsztunku bojowego (szabli, czekana) oraz gotówki. W odpowiedzi dzierżawca Łyśca twierdził, że Kawecki z towarzyszami miał zbrojnie napaść na gospodę, pochwycić sługę skarżącego i przy pomocy tortur (wkręcanie palców w kurek) wymusić na nim niekorzystne dla Piekarskiego zeznania, do czego doszło za zgodą rotmistrza Odrowskiego, ponadto przy tej okazji zraniono go oraz obrabowano, łupem złoczyńców miały paść m.in. trzy konie oraz 322 zł w gotów$c^{51}$. Bez znajomości dalszego biegu sprawy nie sposób przesądzić, która ze stron miała $\mathrm{w}$ tym sporze rację.

Część skarg żołnierskich dotyczy napaści ze strony szlachty czy chłopów w przypadku tych ostatnich inspiratorami zajścia mogli być miejscowi urzędnicy - na pojedynczych towarzyszy wraz z ich pocztami, co zwykle kończyło się rabunkiem i uszkodzeniem ciała napadniętych. Dla przykładu lisowczyk Aleksander Szyjarski skarżył się - w imieniu swoim oraz towarzysza Jana Minczewicza - na Jana Sędzickiego i Mikołaja Rybczewskiego, którzy jakoby napadli na jego kwaterę zranili oraz zabrali dobytek wraz z rynsztunkiem. W dołączonym do protestacji rejestrze utraconych rzeczy rzuca się w oczy kielich mszalny, który, jak twierdził poszkodowany, został odebrany heretykom w Niemczech i przywieziony z zamiarem ofiarowania jako wotum bliżej nieokreślonemu kościołowi ${ }^{52}$. Dla odmiany Krzysztof Śleszyński, szlachcic z powiatu łęczyckiego oraz towarzysz roty Jana Sobieszczańskiego, oskarżał urzędników i poddanych z niewymienionej z nazwy wsi położonej milę od Zbaraża (?), że napadli go w czasie postoju w karczmie, zabierając wozy wraz z końmi, a do tego pobili i związali czeladźs ${ }^{53}$.

${ }^{51}$ CDIAUL, f. 5, op. 1, 120, s. 242-244.

${ }^{52}$ CDIAUL. f. 13 , op. 1 , spr. 339, s. 1589-1596.

${ }^{53}$ CDIAUL, f. 9, op. 1, spr. 374, s. 492-493; zob. ibidem, f. 1, op. 1, spr. 206, s. 87, okazanie ran Stanisława Drewnowskiego, pachołka Baltazara Leszczkowskiego, towarzysza z chorągwi kasztelana bełskiego Stanisława Żórawińskiego, zadanych przez Pawła Ćwiklińskiego, famulusa i dzierżawcę wsi Chorobrów, należącej do Andrzeja Młockiego; ibidem, s. 632-633, skarga uczciwego Jakuba Zakłockiego, żołnierza w chorągwi Wojciecha Sulimierskiego przeciwko Matiaszowi Przemińskiemu, który miał nasłać na skarżącego swoich pachołków i odebrać mu pieniądze wraz z koncerzem; ibidem, f. 17, op. 1, spr. 114, s. 867-869, skarga Andrzeja Uhernickiego, towarzysza z chorągwi Olbrachta Odorowskiego przeciwko Annie z Jabłonowca, wdowie po Stanisławie Kaszowskim, która wespół z Pogroszowskim, dzierżawcą Chmielowej miała pojmać i obrabować protestującego we wsi Chmielowa; NGAB, fond 1740, opis 1, dzieło 4, k. 621v., skarga towarzysza 
W zaledwie kilku skargach pojawia się wątek zranienia lub zabicia żołnierza czy żołnierzy. Jerzy Rewiński, szlachcic i sługa Krzysztofa Podkamera (Puttkamera?), porucznika kompanii Jana Denhoffa, skarżył się na poddanych ze wsi Zapisy, należącej do Reginy Żółkiewskiej, o napaść i zadanie wielu ran ${ }^{54}$. W innej skardze Jan Mietelski, towarzysz z chorągwi lisowskiej Stanisława Jędrzejowskiego, okazał ciało Andrzeja Kołomiejskiego, sługi Stanisława Niedźwieckiego, towarzysza i chorążego tejże jednostki, zabitego przez młynarza ze wsi Suchodoły i jego wspólników ${ }^{55}$.

Niezwykła przygoda spotkała Jędrzeja Płoskiego, który służył u swego imiennika, Tyszowskiego, w chorągwi lisowskiej Stanisława Stroynowskiego. Karczmarka Zofia Kurczyczka - w której gospodzie Płoski pielęgnował chorego konia - wskazała go jako przestępcę i koniokrada przejeżdżającemu nieopodal towarzystwu chorągwi husarskiej Andrzeja Firleja, starosty kazimierskiego. Podkomendni pana starosty zamierzali odebrać mu konie i ,podespektować”, ale sprytny pachołek zdołał uciec, pozostawiając u Kurczyczki jedynie konia ${ }^{56}$.

Bodaj najbardziej spektakularne zajście miało miejsce 28 października $1620 \mathrm{r}$. w Beresteczku, miasteczku należącym do księcia Aleksandra Prońskiego. Jeśli wierzyć protestacji zaniesionej do grodu buskiego przez towarzyszy chorągwi wojewody ruskiego Jana Daniłowicza, kiedy oddział stacjonował w Busku, grupa towarzyszy i czeladzi została wyprawiona po staje do starostwa łuckiego i przy okazji zatrzymała się właśnie w Beresteczku, gdzie zaatakowali ją mieszczanie, podżegani przez książęcego urzędnika Jana Jaskmanickiego. Zajmowane przez żołnierzy kwatery oblężono i zdobyto, zwycięzcy mieli zabrać konie, siodła, szable, odzież, broń palną (półhaki, rusznice itp.) oraz gotówkę, zabijając przy okazji dziesięciu oraz raniąc dziewięciu żołnierzy. Na domiar złego Jaskmanicki uwięził w lochach zamkowych ocalałych z pogromu towarzyszy i pocztowych. Wśród poszkodowanych znalazł się nawet porucznik chorągwi, nazwiskiem Bogucki ${ }^{57}$.

Osobną grupę protestacji stanowią zarzuty rotmistrzów piechoty, skierowane pod adresem miast oraz dzierżawców dóbr królewskich, którzy mieli odmó-

z roty Zbigniewa Gorayskiego, Piotra Sitańskiego przeciwko szlachetnemu Klemensowi Rodziewiczowi o napaść na kwaterze oraz rabunek broni i precjozów.

${ }^{54}$ CDIAUL, f. 9 , op. 1, spr. 374, s. 646; zob. ibidem, f. 15, op. 1, spr.146, s. 1073-1074, f. 15 , op. 1, spr. 146, s. 1073-1074, skarga Adama Rybińskiego, towarzysza z chorągwi Prokopa Sieniawskiego, przeciwko podkomorzemu sanockiemu, Samuelowi Sienieńskiemu o zranienie sługi protestującego, Samuela Balickiego.

55 CDIAUL, f. 17, op. 1, spr. 114, s. 952-953; zob. ibidem, s. 928-929, 28 lipca 1621 r., protestacja Alberta Glarcka (?) w imieniu jego pana Paula Foxa, rotmistrza pieszego JKM o zabójstwo podkomendnego, uczciwego Janusza z Wieliczki przez szlachciców Borowskiego i Nowosielskiego oraz poddanych ze wsi Słobódka.

${ }^{56}$ CDIAUL, f. 9, op. 1, spr. 374, s. 652-653.

${ }^{57}$ CDIAUL. f. 3, op. 1 , spr. 13, s. 1-8. 
wić udzielenia pomocy w czasie organizacji oraz przemarszu jednostek do obozu. Arnulf Bartoszewski, prowadzący również działa do obozu chocimskiego, skarżył się na mieszczan lwowskich, że pomimo przedstawienia im stosownego mandatu królewskiego, nie zechcieli dostarczyć mu wozów, dział oraz robotników do naprawy dróg ${ }^{58}$. Jakub Folerton, agent Archibalda Carmichaela, któremu monarcha polecił spisanie Szkotów przebywających w Rzeczypospolitej w związku z wyprawą przeciwko Turkom, zarzucał Stanisławowi Pruszkowskiemu, dzierżawcy Szczekocin oraz Szkotowi imieniem George, że nie chcieli wydać Folertonowi dwóch innych przedstawicieli tej samej nacji ${ }^{59}$. Również w przypadku tych protestacji należy zachować ostrożność w ocenie postawy obu stron, o czym świadczyć może przypadek rotmistrza piechoty wybranieckiej z województw lubelskiego oraz bełskiego, Stanisława Słupskiego, którego podkomendny Bartłomiej Kędzierski skarżył się na magistraty Lublina, Urzędowa oraz Kazimierza nad Wisłą, jakoby odmawiały wydania mu zwyczajowo przyjętej liczby żołnierzy wraz z wyposażeniem oraz wozami. W odpowiedzi magistrat lubelski ripostował, że oddział Słupskiego stacjonował na przedmieściach Lublina oraz we wsi Konopnica od stycznia 1621 r., wybierając nielegalnie stacje pieniężne oraz podwody ${ }^{60}$.

Istotną grupą wzmianek dotyczących dyscypliny tworzą skargi dotyczące dezercji oraz szkód wyrządzanych żołnierzom przez ich towarzyszy broni, z tej samej albo innej chorągwi. „Artykuły wojenne” w artykule ósmym zabraniały służbie - pod groźbą bliżej nieokreślonej kary - opuszczania towarzyszy. Pomimo to w księgach grodzkich zachowały się cztery skargi towarzyszy przeciwko służącym, którzy nie dość, że uciekli z wojska, to jeszcze okradli swoich chlebodawców nim poczet dotarł do obozu ${ }^{61}$. Niewykluczone, że w toku gorączkowej rekru-

${ }^{58}$ CDIAUL, f. 9, op. 1, spr. 374, s. 643-644; warto także dodać, że w ten sam rotmistrz oskarżał mieszczan lubelskich o bezprawne zatrzymanie dwóch dziesiętników oraz sześciu żołnierzy, ibidem, s. 642-643; zob. CDIAUL, f. 17, op. 1, spr. 114, s. 881-884, trzy protestacje złożone przez Jana Podbilskiego, porucznika oraz rotmistrza Jerzego Pienickiego z powiatu ciechanowskiego, dowódcę roty pieszej, przeciwko kasztelanowi wyszogrodzkiemu i staroście łomżyńskiemu Marcinowi Kossobuckiemu, niewymienionemu z imienia Grzybowskiemu, Janowi Daniłowiczowi, wojewodzie ruskiemu, którzy odmówili wpuszczenia żołnierzy do swoich starostw: łomżyńskiego, płockiego (sic!) oraz Parczewa.

${ }_{59}$ ANK, księgi grodzkie krakowskie, rkps 46, s. 745-746.

${ }^{60}$ APL. RMO 51, k. 202v., 236v.-237; zob. ibidem, k. 674-674 v., k. 684v.-685; skarga rotmistrza Floriana Stockiego, dotycząca problemów z zebraniem chorągwi z powodu obstrukcji niewymienionych z nazwy miast; skarga tegoż na Jana Kochanowskiego, łowczego JKM i starostę kozienickiego, którego ludzie mieli napaść na służbę Stockiego, wiozącą z Gdańska broń i sukno dla piechoty, ale na k. 669v., skarga Jana Lenczowskiego przeciwko Stockiemu o zbrojną napaść na kwaterę w Lublinie i zadanie ran.

${ }^{61}$ CDIAUL, f. 9, op. 1, spr. 374, s. 649-650 skarga Eliasza Melechowicza, Dzianaja Hajderowicza oraz rotmistrza Abrahama Kińskiego, przeciwko sługom, którzy dopuścili się kradzieży 
tacji znacznej liczby żołnierzy oraz służby na kampanię chocimską, towarzysze korzystali z usług nieznanych sobie wcześniej ludzi, którzy następnie - korzystając ze sposobności, jaką dawało wielkie, jak na warunki koronne miasto - uciekali wraz z rzeczami swych chlebodawców.

Szczególny przypadek zdarzył się staroście kamienieckiemu, pisarzowi polnemu koronnemu Stefanowi Potockiemu,który powierzył swemu słudze, Tymkowi Strutyńskiemu osiem tysięcy złotych otrzymanych ze skarbu na potrzeby własnej chorągwi husarskiej, jak również spory zapas sukna. Strutyński nie był w stanie rozliczyć wydatków na kwotę 800 zł oraz wskazać sposobu dysponowania karazją, kirem oraz falendyszem. W związku z tym wyjechał z obozu pod pozorem zabrania ze Lwowa rejestru wydatków, ale dojechał jedynie do Podhajec, gdzie ukrył się przed Potockim ${ }^{62}$.

Przypadki dezercji zdarzały się tak w przypadku piechoty polskiej, jak i jazdy. Zgodnie z „Artykułami wojennymi”, które w tej kwestii odwoływały się do konstytucji sejmu 1593 r. „Obrona z kwarty”, szlachcic opuszczający chorągiew bez zgody rotmistrza podlegał karze infamii, co jednak nie odstraszyło Eliasza Widawskiego oraz niejakiego Jeżewskiego, którzy po wzięciu pieniędzy opuścili chorągiew powiatową województwa łęczyckiego rotmistrza Marcina Zaleskiego. Jeszcze gorzej zachował się Jakub Podstolski, który nie dość, że uciekł z chorągwi husarskiej Mikołaja Gniewosza, to jeszcze na dodatek zebrał wokół siebie kupę swawolną liczącą kilkadziesiąt koni, na czele której dopuścił się licznych przestępstw ${ }^{63}$. Trzech podkomendnych Arnulfa Bartoszewskiego zdezerterowało wraz z rynsztunkiem, podobnie postąpili także podkomendni Grajewskiego ${ }^{64}$. Odmiennie postąpili czterej towarzysze z chorągwi starosty lwowskiego Stanisława Bonifacego Mniszcha, którzy odebrawszy pieniądze za służbę przeszli do chorągwi Mączalskiego, choć „Artykuły wojenne” zakazywały w artykule szóstym tego rodzaju postępowania ${ }^{65}$. Względnie niewielką liczbę tego rodzaju wzmianek thumaczyć może fakt, że wiele podobnych zdarzeń miało miejsce w obozie, gdzie podlegały jurysdykcji sądu hetmańskiego.

Należałoby w tym miejscu przywołać nieliczne, odnotowane w księgach grodzkich wzmianki o ranach odniesionych przez żołnierzy z rąk towarzyszy z tej samej chorągwi. Jeszcze w grudniu 1620 r. Wojciech Stokowski oraz Mikołaj Włyński, towarzysze roty Tomasza Zamoyskiego pod dowództwem rotmistrza

i uciekli; APL RMO 51, k. 642-642 v., skarga Marcjana Sierakowskiego, łowczego ziemi gostyńskiej, towarzysza chorągwi kasztelana sochaczewskiego Konstantego Plichty, przeciwko służącym o kradzież oraz ucieczkę.

${ }^{62}$ CDIAUL, f. 9, op. 1, spr. 374, s. 438-439.

${ }^{63}$ CDIAUL, f. 17, op. 1, spr. 114, s. 902; APL, RMO 51, k. 271v.

${ }^{64}$ CDIAUL, f. 9, op. 1, spr. 374, s. 642-643; ibidem, f. 1, op. 1, s. 622.

${ }^{65}$ CDIAUL, f. 9, op. 1, spr. 374, s. 706. 
Jana Świeżyńskiego protestowali przeciwko Mikołajowi Kozyckiemu, który miał się dopuścić w Kamionce zabójstwa towarzysza tej samej jednostki, Jana Staropińskiego, a następnie, pomimo złożenia przysięgi, nie stawił się na termin rozprawy sądowej wyznaczony przez rotmistrza. Pół roku później, w czerwcu $1621 \mathrm{r}$. Krzysztof Jabłoński, towarzysz z chorągwi lisowskiej Stanisława Jędrzejowskiego, okazał rany zadane mu przy użyciu broni palnej przez Kaspra Piotrowskiego. Nie znamy bliższych szczegółów zdarzenia, wiadomo tylko, że tak poszkodowany, jak i jego ofiara wywodzili się z powiatu liwskiego na Mazowszu. Podobnie Wojciech Kurzejawski (?), famulus Jana Rusieckiego, towarzysza w chorągwi Jana Rozrażewskiego, skarżył się na innego sługę tegoż żołnierza, niejakiego Morawskiego, o zranienie ${ }^{66}$. Odmienny charakter miała skarga grupy szlacheckich podkomendnych Daniela Hebrona, który wbrew zawartej z nimi w czasie zaciągu w okolicach Wielkiej Nocy umowie zapłacił wyłącznie za jeden kwartał służby, jednakże bez umówionej kontentacji ${ }^{67}$.

Zdecydowana większość skarg dotyczących szkód powstałych wskutek działania żołnierzy z innej chorągwi dotyczyła napaści w miejscu noclegu, zwykle w karczmie lub domu prywatnym, co zwykle kończyło się obrabowaniem lub zranieniem napadniętego, do zabójstw dochodziło rzadziej. Czynów tego rodzaju zabraniały „Artykuły wojenne”, które jednakowoż w kwestii określenia kary ograniczały się do informacji o „srogim karaniu” (art. 10). Do zajść dochodziło tak w miastach, jak i na wsi. W styczniu $1621 \mathrm{r}$. rotmistrzowie piechoty węgierskiej, István Saroszy oraz Mihal Ustwaroszy oskarżali rotmistrza jazdy kozackiej Rafała Lipnickiego o napaść na kwatery odpowiednio w Bieczu oraz Pilźnie, do której doszło z użyciem broni palnej, a której następstwem były rany węgierskich piechurów ${ }^{68}$. Dla odmiany, w czerwcu rajtarzy Marcina Zaleskiego nie wpuścili

${ }^{66}$ CDIAUL, f. 3, op. 1, spr. 13, s. 20-21; ibidem, f. 17, op. 1, spr. 114, s. 862; APL, RMO 51, k. $613 \mathrm{v}$.

${ }^{67}$ APL, RMO 51, k. 703v.-704.

${ }^{68}$ ANK, księgi grodzkie bieckie, rkps 170, s. 1037-1039, 1099; dwa miesiące później Saroszy złożył podobną skargę przeciwko podkomendnym rotmistrza Jana Kazimierskiego, ibidem, księgi grodzkie krakowskie, rkps 46, s. 734; warto jednak odnotować przypadki odwrotny, jak choćby wtedy, kiedy piechurzy rotmistrza Jerzego Pieńkowskiego mieli napaść na czeladź Krzysztofa Gigonta, towarzysza z roty Jana Sobieszczańskiego, zmierzającą do obozu. Słudzy zostali pobici i obrabowani, tracąc m. in. konie oraz broń, CDIAUL, f. 9, op. 1, spr. 374, s. 481-482; inne przypadki starć na kwaterach w mieście zob. CDIAUL, f. 13, op. 1, spr. 339, s. 1291-1300, skarga Stanisława Stroynowskiego, pułkownika JKM wojska lisowskiego przeciwko Gniewoszom: rotmistrzowi husarskiemu Mikołajowi oraz kozackiemu Krzysztofowi o napaść w Przemyślu, wraz z okazaniem ciała zabitego rzekomo przez podkomendnych Gniewoszów Stanisława Jaworowskiego; ibidem, f. 17 , op. 1, spr. 146, s. 862-864, skarga towarzysza z chorągwi Tomasza Zamoyskiego, Jędrzeja Skowrona przeciwko Wieszczyckieemu, porucznikowi chorągwi kasztelana poznańskiego Piotra z Bnina Opalińskiego o napaść na kwaterę w Tarnopolu. 
piechoty pod dowództwem Wojciecha Zaliwskiego i Waleriana Falęckiego do Kamionki Strumiłowej, witając nieproszonych gości ogniem z broni palnej ${ }^{69}$.

W maju towarzysze z chorągwi lisowskiej Idziego Kalinowskiego zarzucało podkomendnym Władysława Stadnickiego, że w czasie spotkania w karczmie Derśniak mieli w niewybredny sposób żartować z lisowczyków - na przykład przyszywając jednemu z nich rękawy szaty do siodła, po czym zaatakować ich szablami, poranić i złupić ${ }^{70}$. Podobne praktyki stały się również udziałem piechoty cudzoziemskiej, na przykład Baltazara Karmichela, kapitana z regimentu Piotra Learmonta, który zarzucał niejakiemu Poledorowi (Krzysztofowi Podkamerowi vel Puttkamerowi), kapitanowi regimentu Denhoffa, dokonanie w Jaryczowie zaboru wozu ze słoniną, beczki sucharów oraz sprzętu wojennego wraz z dwoma końmi, które Poledor zabrał ze sobą do Lwowa ${ }^{71}$.

W ramach podsumowania należałoby powiedzieć, że przygotowania do wojny chocimskiej oznaczały dla ludności cywilnej, zwłaszcza zamieszkującej tereny położone na trasie przemarszu wojska albo w pobliżu miejsc obozowania poważne problemy, związane ze szkodami wyrządzanymi przez niezwykle liczną armię koncentrującą się do walki przeciwko wojskom Osmana II. Rzeczywista skala szkód jest jednak trudna do oszacowania. W literaturze przedmiotu zwracano uwagę na zawodność protestacji jako źródła do oszacowania wysokości szkód ${ }^{72}$. Zebrany w toku kwerendy materiał również daje podstawę do podejrzeń co do uczciwości składających skargi, zwłaszcza wówczas, gdy różne oddziały wojskowe odwiedzały kilkakrotnie miasto lub wieś, a pomimo to skala szkód podanych w protestacji jest w każdym przypadku zbliżona. Zwraca jednak uwagę zbliżony katalog rzeczy, które padały łupem wojskowych łupieżców: żywność, przedmioty żelazne, ubrania, zwierzęta hodowlane, zwłaszcza drób, bydło i konie pojawiają się w większości protestacji.

Wzrost liczebny armii, korzystającej w toku przemarszu z tych samych traktów i obozującej w tych samych miejscach prowadził do wzrostu liczby starć

${ }^{69}$ CDIAUL, f. 9, op. 1, spr. 374, s. 523-525.

${ }^{70}$ ANK, księgi grodzkie bieckie, rkps 170, s. 1233-1235, co ciekawe, Kalinowski, który był „,biczem bożym” dla ludności cywilnej, często skarżył się na szkody wyrządzane mu przez innych żołnierzy, zob. CDIAUL, f. 13, op. 1, spr. 339, s. 1129-1135, dwie skargi towarzystwa Kalinowskiego przeciwko podkomendnym Mikołaja Stogniewa, porucznika chorągwi husarskiej królewicza Władysława Zygmunta Wazy.

${ }^{71}$ CDIAUL, f. 9, op. 1, spr. 374, s. 582.

${ }^{72}$ M. Nagielski, Żotnierz koronny..., s. 145, problem dotyczył zresztą także szacowania szkód w toku zwykłych postępowań sądowych poza terenem Rusi Czerwonej oraz Małopolski, zob. A. Moniuszko, Wybrane aspekty ekonomiczne funkcjonowania sadownictwa grodzkiego i ziemskiego na Mazowszu w pierwszej połowie XVII wieku, [w:] D. Wereda (red.), Nad społeczeństwem staropolskim, t. II, Polityka i ekonomia - Społeczeństwo i wojsko - Religia i kultura w XVI-XVIII wieku, Siedlce 2009, s. 53-56. 
pomiędzy różnymi oddziałami, czemu skądinąd trudno się dziwić. Żołnierze byli niejako skazani na rywalizację w warunkach ograniczonego dostępu do środków aprowizacyjnych, co niejednokrotnie kończyło się zwadą, w której po obu stronach padali ranni, a nawet zabici. Zawiodło także państwo, które nie podjęło żadnych prób zorganizowania magazynów z żywnością oraz rynsztunkiem. Niewiele pomagało wysyłanie uniwersałów, nakazujących żołnierzom możliwie jak najszybsze przybycie do obozu, ani wysyłanie komorników w celu zbadania rozmiarów poczynionych przez wojsko szkód ${ }^{73}$. Nie wydaje się, aby monarcha zdecydował się na powołanie urzędnika odpowiedzialnego za aprowizację armii w toku kampanii, choć takie przypadki zdarzały się już wcześniej za jego panowania. Co więcej, propozycje powołania prowiantmagistra zostały zgłoszone przez Jerzego oraz Krzysztofa Zbaraskich w toku obrad sejmu 1620 r., a niedługo po zakończeniu zmagań z Portą Ottomańską król czynił starania, aby stworzyć podobny urząd w Wielkim Księstwie Litewskim ${ }^{74}$. Na usprawiedliwienie króla i jego urzędników można dodać, że problem z logistyką wojskową miała podówczas większość państw europejskich ${ }^{75}$.

Poczyniona w toku badań nad przestępczością oraz dyscypliną w szeregach armii przed wojną chocimską kwerenda ujawniła także ograniczenia ksiąg grodzkich relacyjnych. Boleśnie odczuwalny jest brak informacji dotyczących dalszego biegu spraw, opisanych w protestacjach. Na podstawie badań prowadzonych w księgach lwowskich za lata 1622-1635 można stwierdzić, że rzadko oblatowano w nich dekrety sądów, tak cywilnych, jak i wojskowych. Konieczne jest zatem sięgnięcie w przyszłości - w miarę możliwości - po inne serie ksiąg grodzkich,

${ }^{73}$ Na przykład CDIAUL, f. 13, op. 1, spr. 339, s. 1531-1532, uniwersał Zygmunta III, Warszawa 27 lipca 1621, oblatowany 16 VIII t. r., adresowany do żołnierzy. Król popędza opieszałe chorągwie do obozu i obiecuje wysłanie komornika, Krzysztofa Świrskiego, aby przeprowadził śledztwo w sprawie szkód poczynionych przez wojsko.

${ }^{74}$ P. Gawron, Organizacja i status prawny armii polsko-litewskiej $w$ Inflantach w latach 1602 1611 [w:] K. Bobiatyński, P. Gawron, K. Kossarzecki, P. Kroll, D. Milewski (red.), Hortus bellicus. Studia z dziejów wojskowości nowożytnej. Prace ofiarowane Profesorowi Mirosławowi Nagielskiemu, Warszawa 2017, s. 157, 171; idem, Projekty reform armii Rzeczypospolitej w latach 20. XVII w. na tle wojskowości zachodnioeuropejskiej, [w:] F. Wolański, R. Kołodziej (red.), Staropolski ogląd świata. Rzeczpospolita między okcydentalizmem a orientalizacją, t. 1: Przestrzeń kontaktów, Toruń 2009, s. 205; H. Wisner, Prowiantmistrz Wielkiego Księstwa Litewskiego 1621-1622, [w:] idem, Rzeczpospolita Wazów. Czasy Zygmunta III i Władysława IV, Warszawa 2002, s. 245-252.

${ }^{75}$ Kastylia: I.A.A. Thompson, War and Government in Habsburg Spain 1560-1620, London 1976, s. 113-116; Anglia: L. Boynton, Martial Law and the Petition of Right, „The English Historical Reviev" 1964, vol. 79, no. 311, s. 256 i n.; Francja: J.A. Lynn, How War Fed War: The Tax of Violence and Contributions during the Grand Siècle, „Journal of Modern History” 1993, vol. 65, no. 2, s. 288 i n..; D. Parrott, Richelieu's Army. War, Government and Society in France, 1624-1642, Cambridge 2001, s. 507-533; Górne Łużyce: Ł. Tekiela, Wojna trzydziestoletnia na Górnych Łużycach. Aspekty militarne, Racibórz 2010, s. 172-202. 
jak również zbadanie problematyki przestępczości i dyscypliny w 1621 r. na innych terenach Rzeczypospolitej, zwłaszcza na Podlasiu i Wołyniu, zwłaszcza, że ślady problemów dyscyplinarnych w wojsku pojawiły się w tym czasie w Prusach Królewskich oraz województwach łęczyckim, sieradzkim i ziemi wieluńskiej ${ }^{76}$.

\section{DISCIPLINE IN THE POLISH-LITHUANIAN ARMY IN LESSER POLAND AND RED RUTHENIA DURING ITS PREPARATION FOR THE EXPEDITION TO KHOTYN IN 1621}

\section{Summary}

In the course of a query into the court record books of the local magistrates' courts dealing with nobles (Polish: sad grodzki), 177 mentions were found which pertained to the discussed subject matter. The majority of the mentions mainly concerned protestations, wound identifications or body identifications of the alleged victims of the prohibited acts. Complaints pertaining to soldiers' behaviour concerned 78 units belonging to almost all types of military formations which were present in the Khotyn's computs (a type of military unit in the Polish-Lithuanian Commonwealth). Moreover, it should be noted that some of the complaints are present more than once on the aforementioned list. The court record books of the local magistrates' courts included reports pertaining to damage done in eight larger municipal districts (Biecz, Bochnia, Lublin, Lviv, Olkusz, Przemyśl, Ternopil, and Sudova Vyshnya) as well as in 76 small towns, villages and landed properties. Among the victims of the crimes, there were residents of nine counties (Polish: starostwo grodowe) and church institutions. Soldiers were also found among the victims of the crimes. The court record books contain 17 instances of crimes where milites from other units (Polish: rota) were the perpetrators as well as 7 instances where the damage was caused due to the actions of their comrades in arms or members of their own retinue (Polish: poczet). Five complaints pertained to desertion and there were 18 cases in which soldiers accused the civilian population of inflicting the damage.

The real scale of the damage is difficult to assess. The data collected in the course of the query also gives cause for distrust regarding the honesty of the complainants. It is especially suspicious when a given town or village was visited by different military units several times. Despite this fact, the scale of the damage stated in the protestations is similar in each and every case. However, one particular thing draws attention, namely, the approximate volume of items which were looted by the military plunderers. Among the stolen items which were mentioned in the majority of the protestations were the following: food, iron articles, clothes, and farm animals, especially poultry, cattle and horses.

The army's growing numbers led to a growth in the number of skirmishes between different units. This is hardly surprising considering the fact that the military units took the

${ }^{76}$ P. Gawron, Oddziały autoramentu cudzoziemskiego w Prusach Królewskich $i$ Warmii w dobie wojny z Moskwa za panowania Zygmunta III Wazy (1609-1618), „Społeczeństwo Staropolskie. Seria Nowa" 2015, t. IV: Spoleczeństwo a wojsko, s. 56; T. Srogosz, Żolnierz swawolny..., s. $193-194$. 
same roads during their marches and they made camp in the same places. Soldiers were, in a way, forced to compete for provisions which were in limited supply. As a consequence, it often led to altercations which resulted in wounded or even killed soldiers on both sides. The state also failed as it did not make any attempts to organize depots with food and equipment. Sending out proclamations (Polish: uniwersat) which ordered soldiers to return to their camp as soon as possible did not help very much either. And sending out bailiffs to assess the scope of damage done by the army was also not effective. As an excuse for the king's and his officials' shortcomings, it needs to be mentioned that military logistics was a problematic issue for the majority of European countries at the time.

\section{DISCIPLINE DANS L'ARMEE POLONO-LITUANIENNE DANS LA REGION DE PETITE-POLOGNE ET LA RUTHENIE ROUGE LORS DES PREPARATIFS DE L'EXPEDITION DE KHOTYN (CHOCIM) EN 1621}

\section{Resumé}

$\mathrm{Au}$ cours de nos recherches, 177 mentions sur la question que nous abordent ont été trouvées dans les livres municipaux. Dans sa grande majorité elles concernaient de diverses plaintes, présentation des blessures ou des corps de victimes présumées d'infractions. Les plaintes relatives aux comportements des soldats concernaient 78 unités appartenant à presque tous les types de formations militaires présentes à l'armée de Khotyn, dont certaines figuraient plus d'une fois sur la liste. Les textes des livres municipaux mentionnaient des dégâts matériels qui ont été enregistrés dans huit assez grandes villes (Biecz, Bochnia, Lublin, Lviv, Olkusz, Przemyśl, Tarnopol, Sądowa Wisznia) et dans 76 petites villes, villages et latifundiums. Parmi les victimes se trouvaient des habitants de neuf starosties municipales et institutions religieuses. Des soldats étaient également des victimes d'actes criminels; les livres recensaient 17 cas où l'auteur était des milites d'autres unités, sept cas où les dommages avaient été causés par des camarades d'armes ou des membres de leur propre détachement. Cinq plaintes concernaient la désertion. Dans 18 cas, des soldats avaient accusé des civils d'avoir causé des dommages.

Cependant, l'ampleur réelle des dégâts est difficile à estimer. Les documents rassemblés au cours de notre recherche suscitent également des doutes quant à la probité des plaignants, en particulier, parce que plusieurs troupes de soldats ont passé nombreuses fois par une ville ou un village, et malgré cela, l'ampleur des dommages rapportés dans les plaintes est similaire. Ce qui attire toutefois l'attention, c'est le volume similaire de choses qui ont été volées par les pillards militaires: de la nourriture, des articles en fer, des vêtements, des animaux de ferme, en particulier de la volaille, du bétail et des chevaux apparaissent dans la plupart des plaintes.

L'accroissement du nombre de soldats dans l'armée, qui empruntaient les mêmes itinéraires pendant leur marche et campaient dans les mêmes endroits, a entraîné une augmentation du nombre d'affrontements entre différentes unités, ce qui n'est guère surprenant. Les soldats étaient en quelque sorte condamnés à la concurrence dans des conditions d'accès limité aux approvisionnements en nourriture, ce qui aboutissait souvent à des bagarres qui faisait des blessés et même des morts des deux côtés. L'État qui 
n'a pas tenté d'organiser des entrepôts de nourriture et du matériel a également échoué. Les efforts consistant à émettre des actes universels ordonnant aux soldats d'arriver au camp le plus vite possible, ou à envoyer des huissiers de justice afin d'évaluer l'étendue des dégâts causés par l'armée donnaient des faibles résultats. Cependant, pour justifier l'inefficacité des actions entreprises par le roi et ses fonctionnaires, il faut dire que de nombreux pays européens étaient confrontés à des problèmes logistiques de leurs armées. 